9-2008

\title{
Breaking the Khaldunian Cycle? The Rise of Sharifianism as the Basis for Political Legitimacy in Early Modern Morocco
}

Stephen Cory

Cleveland State University, s.cory@csuohio.edu

Follow this and additional works at: https://engagedscholarship.csuohio.edu/clhist_facpub

Part of the History of Religion Commons, and the Islamic World and Near East History Commons How does access to this work benefit you? Let us know!

\section{Publisher's Statement}

This is an Author's Accepted Manuscript of an article published in the Journal of North African Studies, September 2008, available online: http://www.tandfonline.com/10.1080/ 13629380701844706

\section{Repository Citation}

Cory, Stephen, "Breaking the Khaldunian Cycle? The Rise of Sharifianism as the Basis for Political Legitimacy in Early Modern Morocco" (2008). History Faculty Publications. 83.

https://engagedscholarship.csuohio.edu/clhist_facpub/83

This Article is brought to you for free and open access by the History Department at EngagedScholarship@CSU. It has been accepted for inclusion in History Faculty Publications by an authorized administrator of EngagedScholarship@CSU. For more information, please contact library.es@csuohio.edu. 


\title{
Breaking the Khaldunian cycle? The rise of sharifianism as the basis for political legitimacy in early modern Morocco
}

\author{
Stephen Cory* \\ Cleveland State University, Cleveland, $\mathrm{OH}$, USA
}

\begin{abstract}
This paper argues that the sharifian Sa'di and 'Alawi dynasties ended the Khaldunian Cycle within Morocco through their development of a political creed based upon sharifianism (the idea that Islamic leadership should be held by descendants of the Prophet Muhammad). Within the context of a growing European threat, the Sa'dis created a doctrine that was both new and distinctly Moroccan while alleging it held a universal application deriving from the time of the Prophet. Thus they institutionalised a sense of 'asabiyah in a way that preceding dynasties could not, which later enabled the 'Alawis to exceed Ibn Khaldun's predicted dynastic lifespan and to lay the groundwork for the future growth of Moroccan nationalism. These developments do not negate the accuracy of Ibn Khaldun's cyclical analysis but rather they represent a transformation of the forces he observed within the context of the dawn of the modern era. An earlier version of this paper was presented at the 2006 AIMS conference in Tangier, Morocco. Research was conducted with support from a Fulbright fellowship in Morocco between January and June 2006.
\end{abstract}

Keywords: Sharif; Ibn Khaldun; Morocco; Sa'dis

\section{Introduction}

In $1146 \mathrm{CE}$ a band of Berber warriors gathered to besiege the city of Marrakesh, capital of the Almoravid Empire. Inspired by the teachings of the religious reformer Abu 'Abdullah Muhammad b. Tumart, who had portrayed himself as the Islamic mahdi, this group sought to bring down a dynasty that it regarded as hopelessly corrupt and religiously suspect. Representing a broad collection of tribes, families and confederations from the High Atlas Mountains, these Berber warriors were a rough and uneducated group mostly consisting of shepherds, farmers and nomads. Yet they shared an ambitious goal and an unbridled determination to achieve it. Toughened by their experience in tribal conflicts and buoyed by religious zeal, the Berber army overwhelmed the defences of the urban metropolis, slaughtering many of its inhabitants. Following the conquest of Marrakesh, this messianic movement (which later came to be known as the Almohads) would sweep on to subjugate other cities, increasing its strength with new recruits from the Atlas mountains, until they controlled lands that included the modern nation of Morocco, the North African coastline to the Libyan desert, and the southern portion of Spain.

In conquering their more culturally advanced urban neighbours, these rural warriors lived out a pattern that had occurred many times before them and would reoccur again after their reign ended. This pattern was first identified and discussed by the fourteenth century North African historian 'Abd al-Rahman ibn Khaldun in his Muqaddimah. Known as the Khaldunian Cycle, Ibn Khaldun's theory postulates that societal leadership originates from rural groups ('umran badawi) that are closely bound together through blood ties or other social bonds. He describes these bonds with the term 'asabiyah (group feeling), ${ }^{1}$ and argues that this quality allows such

*Email: stchcory@aol.com 
groups to fight more effectively and zealously than the armies of the citied states ('umran hadari). However, once the new groups establish their empires, they begin to lose their 'asabiyah as a consequence of acquiring the luxuries of settled life. Ibn Khaldun argues that dynasties generally do not last more than three generations because the third generation is challenged by a new group from the hinterlands, repeating the original cycle.

Ibn Khaldun developed this theory based upon his observation of Islamic states, particularly the rise and fall of dynasties in North Africa. His analysis effectively describes the history of such states throughout the medieval and late medieval periods. However, during the sixteenth and seventeenth centuries, Morocco fell under the control of two dynasties (the Sa'dis and 'Alawis) that would base their rule upon sharifianism, the idea that Islamic leadership should be held by direct descendants of the Prophet Muhammad (shurafa', sing. sharif). The 'Alawi dynasty has vastly exceeded Ibn Khaldun's expectations, extending its rule to this day, some 340 years after first establishing its authority throughout the land.

Is the sharifian ideology of political legitimacy responsible for successfully breaking the Khaldunian cycle in Morocco? If so, how and why did it triumph? This paper argues that sharifianism, as developed under the Sa'dis, drew upon strongly held religious values challenged by the changing circumstances of growing European power. In this environment, the Sa'dis created a sharifian political creed which they reinforced for their subjects through public presentations of panegyric literature, highly symbolic ceremonies, and messianic religious imagery, institutionalising a sense of 'asabiyah in a way that preceding dynasties could not. Although the Sa' dis were brought down by internal strife during the seventeenth century, this sharifian 'asabiyah enabled the 'Alawis to rapidly gain control of the country, establish their family at the head of a new sharifian elite, fend off multiple challenges to their authority, and far surpass the three generations of rule predicted by Ibn Khaldun. Thus, the 'Alawis succeeded in breaking the Khaldunian cycle in Morocco. However, this case does not so much negate the accuracy of Ibn Khaldun's cyclical analysis as it represents a transformation of the forces he observed within the context of the dawn of the modern era.

\section{The impact of Ibn Khaldun}

There is no doubt that Ibn Khaldun was the most influential North African historian ever, despite the fact that his work was little noticed by his own society for several centuries after his death. Discovered by French Orientalists in the nineteenth century, Ibn Khaldun's writings have been translated into at least 11 languages and have been analysed in countless scholarly monographs during the past 200 years. His Muqaddimah, which seems to have been intended as an introduction to his major historical work, Kitab al-'Ibar, has been of particular interest to scholars from many disciplines. Among other things, the Muqaddimah provides a detailed discussion of Ibn Khaldun's theory for explaining the grand patterns of world history, the so-called Khaldunian Cycle summarised above.

Not surprisingly, there is considerable disagreement over how to interpret his work. Ibn Khaldun has alternately been compared with Machiavelli, Montesquieu, and Marx, has been credited with being the father of the modern science of sociology, and has been repeatedly hailed as a shining light of intellectual brilliance in the midst of Arab decline, almost as if he was completely disconnected from the culture in which he lived. ${ }^{2}$ Recent scholarship has attempted to correct this unbalanced view by reconsidering the theories of Ibn Khaldun against the backdrop of Arab historical writing and the political and intellectual realities of Ibn Khaldun's age (Khalidi 1994, Simon 2002). Regardless of how he is interpreted, few writers question the brilliance and prescient nature of his work. ${ }^{3}$ 
A measure of his influence can be seen in the fact that one of the greatest modern historians of the Middle East, Albert Hourani, repeatedly references the theories of Ibn Khaldun in his magnum opus, A history of the Arab peoples (1991). In discussing the seemingly endless parade of Islamic dynasties in the Middle East between the ninth through the fourteenth centuries, Hourani utilises Ibn Khaldun's framework to explain the underlying forces that dominated this era. 'The most systematic attempt to explain why dynasties fell victim to their own weaknesses', writes Hourani, 'was that of Ibn Khaldun ... (His explanation provides) the context within which what may seem to be the meaningless procession of dynasties in Islamic history can be understood' (pp. 209, 212).

If Ibn Khaldun's influence upon current understandings of Arab history has been profound, his interpretation of the history of the Maghrib has provided the dominant paradigm for later historical writing on the subject. Ibn Khaldun's texts provide a rich resource for interpreting the history of North African societies. Kitab al-'Ibar has much to say about the two major peoples of the Maghrib, Arabs and Berbers, and their interaction with one another over the centuries. Ibn Khaldun recounts North African historical developments as a means of illustrating his cyclical view of history. Later historians have accepted his general presuppositions while tweaking them slightly to apply in different settings, even in reference to historical periods that followed the death of Ibn Khaldun.

Do Ibn Khaldun's theories really apply to the subsequent history of the Maghrib? Or are they, as Róbert Simon argues, time bound between the era of camel domestication and the development of modern military technologies that brought Bedouin societies more effectively under the control of settled societies and 'meant the end of this cyclical process' (2002, p. 148)? If indeed the Khaldunian Cycle has been broken in Morocco, what specific developments in Moroccan history led to this change? In order to answer these questions, it is necessary to review the ways in which the Khaldunian Cycle has been used to explain Moroccan history, both prior to and following the time of Ibn Khaldun.

\section{Ibn Khaldun and Moroccan history}

The founding Islamic dynasty in Morocco was the Idrisids, a sharifian family that ruled portions of the country between 788-986 CE. Born and raised in Arabia, Idris b. 'Abdullah is said to have fled from Abbasid persecution to the farthest West, where he established his authority among Awraba Berbers near the ancient Roman city of Volubilis. Declaring himself a descendant of the Prophet's grandson, Hasan, Idris extended his rule throughout northern Morocco. However, his reign was cut short when the Abbasid caliph Harun al-Rashid had him poisoned in 791. He was succeeded by a son of the same name, who was born to a Berber concubine after Idris' death. Apparently gifted with abundant political talent and charisma, Idris II assumed leadership of the nascent state at the age of 11 . He is credited not only with founding the city of Fez, but also with establishing a state that stretched from the Sus in the south to Oran in the northeast. ${ }^{4}$ His kingdom was divided among his descendants, who maintained sharifian political authority in northern Morocco for almost 160 years after Idris II died in 828 .

Although few primary sources survive from their era, the Idrisid political ideology seems to have been based upon the assumption that their right to rule was derived from their sharifian identity. ${ }^{5}$ Yet, they never built a strong centralised state, ruling instead through a decentralised family confederation that was unable to unite against interference from outside powers such as the Shi' ite Fatimids based in Ifriqiyya or the Andalusian Umayyads. Rather than develop their own 'asabiyah, the Idrisids seem to have utilised the 'asabiyah of Berber tribes who supported their rule. For this reason, Ibn Khaldun maintains that the Idrisid state was sharifian in name only, while being predominantly controlled by Berbers. 'If they rendered the oath of allegiance 
to Idris', he writes, 'his rule over them cannot be considered an Arab rule, because the Berbers were in charge of it, and there were not many Arabs in it' (Ibn Khaldun 1967). In this way, the Idrisids differed from the later sharifian dynasties, although their example would serve as inspiration for the rise of sharifianism in the fifteenth century.

Devotion to Islam and combating heresy seem to have provided more secure sources of political legitimacy than a specific sharifian identity between the mid-tenth and the fifteenth centuries. After the Idrisids, political authority in Morocco was disputed between a number of contestants, including the Fatimids, the Andalusian Umayyads, and several Berber and Kharijite groups, until the rise of the Almoravid dynasty from the Western Sahara in the mid-eleventh century. Conquering Morocco and al-Andalus from the south, the Almoravids were the first of three Berber dynasties (Almoravids, Almohads, and Merinids) whose rule closely fits the paradigm described by Ibn Khaldun. ${ }^{6}$ All three dynasties initially came from the desert or mountain regions to conquer the settled areas. Once in control of the cities, all three dynasties achieved considerable wealth, embellished their capitals with imposing architectural monuments, and developed sophisticated urban cultures. None of their empires lasted more than 150 years, and all fell victim to the armies of new rural-based dynasties, most of whom were inspired by different forms of religious revivalism. ${ }^{7}$

The applicability of the Khaldunian Cycle to the medieval Maghrib should not surprise us, for Ibn Khaldun was a keen observer of his own society. He was born in Tunis in 1332, at a time when the Merinid dynasty reigned in Morocco. North African unity, briefly achieved under the Almohads in the late eleventh and early twelfth centuries, was a distant memory by the time of Ibn Khaldun. The Hafsid state of Tunisia claimed to be descended from the Almohads, but it struggled with the "Abd al-Wadids of Tlemcen and the Merinids of Fez over the right to lay claim to the Almohad legacy. Ibn Khaldun served in the courts of all three states, as well as that of the Nasrids of Granada, during a political career that spanned 30 years in the Maghrib. By the time he left Tunis in 1382 to take up permanent residence in Cairo, Ibn Khaldun had developed his theory of the Khaldunian Cycle and had produced his first draft of the Muqaddimah.

A number of historians have argued that Ibn Khaldun's theories arose directly from his frustration with the contemporary political situation in the Maghrib. 'In his attempt to understand the anarchy into which the kingdoms of the Maghreb had been plunged', writes Yves Lacoste, '(Ibn Khaldun) had to go beyond the incoherence of purely factual history, make generalisations and establish correlations between various categories of events. This approach led him to a global conception of history, to an analysis of social and political structures and to a study of their evolution' (1984, p. 63). Others have pointed out that Ibn Khaldun's career provided him with extensive contact both with settled urban society (in which he was raised and lived most of his life) and semi-nomadic rural societies (among which he sometimes worked as a representative of the sultan, and among which he lived for four years at Qalat Ibn Salama in Algeria, where he wrote the first draft of the Muqaddimah). As he considered the impact of these vastly different ways of life upon the history of the Maghrib, Ibn Khaldun observed that 'umran badawi seemed to repeatedly serve as the source for the rise of 'umran hadari and that the achievement of powerful citied states ultimately led to the decline and fall of the groups that had established these states. In attempting to understand what it was that enabled nomadic societies to conquer settled civilisations, Ibn Khaldun developed his concept of 'asabiyah.

Thus, the theory of the Khaldunian Cycle was developed with the Maghrib in view and it seems to accurately describe the rise and fall of dynasties in North Africa, including Morocco, at least through the beginning of the fifteenth century, when Ibn Khaldun died. However, many modern historians also view the ideas of Ibn Khaldun as being applicable to historical developments that took place after his death. For instance, Dahiru Yahya places the history of the Sa'di dynasty within the context of the Khaldunian cycle. Yahya writes: 
The Sa' di dynasty roughly fits into Ibn Khaldun's categorisation. The first generation ... witnessed the establishment of the dynasty and all the great military exploits which made possible its establishment. The second generation ... was a period of consolidation and splendour, but the idealism that formed the basis of the dynasty was lost. The third generation and part of the fourth ... was a period of complete chaos and degeneration when Sa'di Morocco was dismembered as a political entity. (1981, p. 6)

Historians have even applied Ibn Khaldun's analysis to modern developments in the Maghrib and the broader Middle East. Nineteenth century French colonial historians revised his idea of the competition between 'umran badawi and 'umran hadari into the prototypical idea of bilad al-makhzan and bilad al-siba, which was used to explain the history of Morocco under 'Alawi rule. ${ }^{8}$ The French also used Ibn Khaldun's discussions about the origins of the Berbers and their conflicts with the Arabs as 'the explanation for the poverty of the country perceived by the French when they conquered Algeria in the nineteenth century' (Brett and Fentress 1996, p. 134). More recently, Malise Ruthven writes, in an afterword to Albert Hourani's A history of the Arab peoples, that Ibn Khaldun's 'theories of cyclical renewal and concept of 'asabiyah ... still provide a useful frame through which to view contemporary events' (Hourani 2005, p. 460). Ruthven then proceeds to analyse developments in the Middle East from 1991-2005 in light of concepts introduced in the Muqaddimah.

\section{The triumph of sharifianism in Morocco}

While the concept of 'asabiyah certainly does have its applications in the modern MENA region, such an approach overlooks significant changes that took place in the Maghrib during the early modern era and fails to address the problem of the longevity of North African dynasties from the sixteenth to seventeeenth centuries on. Indeed, the political landscape of Morocco underwent a substantial transformation during the fifteenth and sixteenth centuries, which would radically alter the process by which dynasties established and maintained their authority. This transformation was connected to the role of the shurafa'.

The connection between shurafa' and political authority in Morocco goes back to the Idrisids, yet sharifianism was weak during the Idrisid era and it represented only one of several different ideologies that competed for authority during the medieval period. ${ }^{9}$ Indeed, sharifianism appeared to have been defeated with the collapse of the Idrisids and their replacement by the Berber dynasties. Although the shurafa' continued to receive honour and many of them possessed local influence in different parts of Morocco, there were no serious attempts to establish sharifian-based political states until the fifteenth century. ${ }^{10}$ The most important sharifian lineage was that of the Idrisids themselves, who had left the political arena and yet continued to base their religious power in Fez, the city of Idris II.

However, the influence of the shurafa' dramatically increased under the Merinid dynasty, which succeeded the Almohads in 1259. The Merinids, who were Zanata Berbers by origin, sought to legitimise their state through demonstrating their commitment to spiritual values. For this reason, they built religious monuments and mosques, encouraged the study of Islam through Qur'anic schools and madrasas, and forged an alliance with the Maliki ulama and the shurafa'. In this alliance, they promoted the power of these two groups in exchange for their support of the state. They honoured the shurafa' by exempting them from taxes, promoting the celebration of the mawlid (the Prophet's Birthday), and placing leading shurafa' into positions of power within their capital city of Fez.

A measure of the rising influence of sharifianism in Morocco can be seen in the writings of the qadi and scholar, Ibn al-Sakkak, who advised the Merinid sultans in the late fourteenth century. Despite Merinid patronage of the shurafa', Ibn al-Sakkak still felt the dynasty was lacking in this area, and he warned them against a failure to show proper honour to the sharifian 
families. In particular, the scholar protested that the Merinid sultan Abu Sa'id Uthman III had neglected to demonstrate sufficient respect for the descendants of the Prophet. This lack of respect included his decision to remove the celebration of the mawlid from among the official state holidays. Ibn al-Sakkak predicted that such neglect would lead to the dynasty's downfall, and his prophecy seemed to come true when Abu Sa'id and his family were murdered during a palace revolt in 1420. Only the sultan's one year old son 'Abd al-Haqq was spared, providing an opportunity for the Wattasid family (cousins and allies of the Merinids) to step in and rule in the Merinid sultan's name. Like their cousins, the Wattasids were Zanata Berbers who sought to establish their legitimacy through religious patronage. ${ }^{11}$

Why would Abu Sa'id cut back on the privileges of the shurafa'? Perhaps he was concerned that they were becoming too powerful. It seems likely that, by the beginning of the fifteenth century, there were signs that sharifian influence had grown beyond the Merinids' ability to control it. In an attempt to re-establish control and appropriate Idrisid 'asabiyah for their own cause, the Wattasids announced in 1437 that they had discovered the tomb of Idris II within the heart of the old city of Fez. Consequently, they established a plaque over the gravesite to assure that proper respect was shown to the remains of the city's founding father and patron saint. ${ }^{12}$ The Wattasids hoped that, as protectors of this holy site within the walls of their capital city, they could derive some political benefits from the rising tide of sharifianism. Thus the predominance of Fez and its Idrisid sharifian elite continued under Wattasid rule.

However, when the Merinid 'Abd al-Haqq took power in his own name in 1458, he cut back upon sharifian privileges and appointed Jewish officials to collect taxes from the Fezzi shurafa' and ulama. As a result of these and other unpopular policies, a mob murdered 'Abd al-Haqq in the streets of Fez in 1465. Following this revolt, a short-lived sharifian republic was established in Fez under the leadership of Idrisid shurafa'. However this quasi-state was crushed in 1471 by Muhammad al-Shaykh al-Wattasi. ${ }^{13}$ Once back in authority over Fez, the Wattasids reestablished their alliance with the ulama and Idrisid shurafa', and sought to avoid the mistakes of the last Merinid sultans.

The revival of sharifian prestige turned out to be a double-edged sword which could also be used against the Idrisids and their Wattasid patrons. At the same time that the Wattasids were establishing themselves as rulers over northern Morocco, the Portuguese began to expand their colonial holdings along the Moroccan Atlantic coast. Under Prince Henry the Navigator, the Portuguese had launched the era of European colonial expansion by conquering Ceuta in 1415. Although the Wattasids managed to hold off the Europeans for several decades, the Portuguese established a string of outposts in Morocco over a span of 50 years beginning in the second half of the fifteenth century. ${ }^{14}$ The inability of the Wattasids to halt this Portuguese expansion, along with the decision by several influential Sufi shaykhs to revoke their support of the Wattasid dynasty, played a major role in the rise of a competing power in the south. ${ }^{15}$

Fueled by zeal to defend their lands against the encroachments of the infidel, the people of the Sus turned to another sharifian family, the Sa'dis. Although they also traced their lineage from Hasan, grandson of the Prophet Muhammad, the Sa'dis represented a rival sharifian power to that of the Fezzi Idrisids. In 1510, the most influential shaykh of the Sus, Sidi Mubarak, suggested that the people turn to the Sharif 'Abu 'Abdallah Muhammad al-Zaydani of Tagmadart for leadership, and a number of the local tribes took an oath of allegiance to the Sharif (Cornell 1998, p. 258). He chose the millenarian title al-Qa'im bi Amri'llah (One Who Has Arisen by the Command of God). Al-Qa'im's open reliance upon mahdist and prophetic imagery, along with his initial backing from regional Sufi shaykhs, gave the Sa' dis the reputation of being jihad warriors, who utilised religious enthusiasm against the Portuguese in their rise to power. An agriculturally rich area, the Sus provided a solid economic foundation, in addition to tribal warriors, to support the Sa'di movement (Cornell 1990). 
Of the Sufi shaykhs who supported the rise of the Sa'dis, the most influential was 'Abdallah al-Ghazwani, a leader of the Jazuliyya Sufi order founded by the fifteenth century saint Muhammad ibn Sulayman al-Jazuli. ${ }^{16}$ In addition to making astounding claims regarding his central role in representing the image of God to Muslims, al-Jazuli emphasised the importance of the descendants of the Prophet, and the necessity of jihad for defending the lands of Islam. Believing themselves to be revivers of religion in a time when moral and religious values had sunk to an all-time low, the Jazuliyya were effective in stimulating a populist movement that ultimately contributed to the downfall of the Wattasid state. They successfully argued that the Wattasids had failed in their roles as upholders of religion and defenders of the Islamic community, and had sold themselves out to the Christian invaders through several treaty arrangements. By undermining the legitimacy of the Wattasids, creating the climate for a general acceptance of the notion that political leadership should be in the hands of the Prophet's descendants, and recruiting large numbers of believers who were ready to support rival claimants for the sultanate, the Jazuliyya effectively paved the way for the Sa'di ascendance to power (Cornell 1983, 1996, 1998).

Mobilising an army of supporters in the south, the Sa'dis defeated the Portuguese in several key battles. They captured Marrakesh from the Berber Hintata confederation in 1525, after which they began to use their sharifian identity as a trump card against the Wattasids. ${ }^{17}$ By 1554, the Sa'dis had reunited the country under sharifian leadership. Early Sa'di leaders such as Muhammad al-Shaykh al-Mahdi drew heavily upon messianic expectations within Morocco, combining mahdist imagery and titles with bold assertions of sharifian authority, as al-Qa'im had done. ${ }^{18}$ The die had been cast. The sharifian movement had obtained a level of political influence that it was never again to relinquish. ${ }^{19}$

Under Ahmad al-Mansur al-Dhahabi (r. 1578-1603), the Sa'di dynasty would achieve the heights of its power, asserting its authority even into the sub-Saharan regions of Timbuktu and Gao, while keeping the more powerful Spanish and Ottoman dynasties from impinging upon Moroccan sovereignty. But, perhaps more importantly, al-Mansur consolidated the alliance between sharifian lineage and political power within Morocco. The sultan's goal was to establish a Western caliphate, the likes of which had not existed since the tenth century Umayyad caliphate of Cordoba, to rival the Ottoman Empire. To back up his claim to the universal caliphate, al-Mansur emphasised his status as a sharif and made use of symbolism and messianic religious imagery through the panegyric writings of court poets and historians, elaborate ceremonies and rituals, an efficient and imposing army, and an ambitious building programme through which he drew attention to the grandeur of his reign. ${ }^{20}$ Through all these media, the sultan highlighted the twin elements of sharifian lineage and caliphal authority.

Perhaps the greatest example of al-Mansur's co-optation of symbolic imagery to support his sharifian and caliphal claims can be seen in the importance that he placed upon the celebration of the mawlid. Although this festival was a fairly late innovation within the Muslim world, it was already an established practice by the beginning of the Sa'di era. Initially developed by the Fatimids in the eleventh century, the mawlid first appeared in the Maghrib under the Muslim principality of Ceuta during the thirteenth century, and later spread to the Nasrids of Granada and the Merinids of Morocco. Even though the later Merinid rulers and the Wattasids allowed royal devotion to the mawlid to slip, the ceremony remained immensely popular within society as a whole. Despite the fact that the sultans no longer hosted large mawlid celebrations within the palace, private and local celebrations continued unabated until the time of Ahmad al-Mansur. ${ }^{21}$

The mawlid turned out to be a particularly significant holiday for al-Mansur, who was able to use mawlid ceremonies as a platform to trumpet the importance of his sharifian lineage and to firmly establish his identity as heir to the prophetic caliphate. The eighteenth century historian al-Ifrani provides us with a detailed description of how the sultan commemorated the Prophet's birthday, along 
with excerpts from poetic recitations that al-Mansur's wazir al-qalam, 'Abd al-'Aziz al-Fishtali, and other Moroccan dignitaries delivered during the celebration. In addition to the account in al-Ifrani, we also have eyewitness reports from Ahmad Ibn al-Qadi, 'Ali al-Tamagruti, al-Fishtali, and Ahmad al-Maqqari. ${ }^{22}$ From the attention these writers give to accounts of this holiday, it is clear that the celebration of the mawlid played a particularly important role in Ahmad al-Mansur's political legitimacy.

Al-Ifrani highlights his account of the mawlid with a long poem that al-Fishtali composed and recited for one of the mawlid celebrations during al-Mansur's reign. ${ }^{23}$ This poem is from a special genre, entitled mawliddiyyat, which was developed for use at mawlid celebrations. It begins with a meditation upon the greatness of the Prophet of Islam, and upon the ways that his coming changed the world forever. But it is not long before al-Fishtali turns his attention from the Prophet to his Sa'di descendent, upon whom he unabashedly showers praise during the course of a holiday that was supposed to be honouring Muhammad. What is distinctive about this poem is the way al-Fishtali dwells upon the sharifian identity of al-Mansur, and goes out of his way to identify the Sa'dis with the prophetic lineage. An example of this can be seen in the following lines:

$\mathrm{He}$ is the imam of men, of the race of 'Ali and of Zaydan, of this noble family who has reigned upon the earth.

These princes are pillars of the Faith, supporters of royal authority, persons whose grand designs elevate them above Saturn....

They are members of this family for which God has established renown ...

Divine Law has noted their grandeur and the verses of the Qur' an have highly proclaimed their superiority.

They are the heirs of the cousin of the Prophet and his executors ...

They are like a tree of glory, planted within the garden of Renown, which has arisen from the incessant showers of Divine Revelation. (al-Ifrani 1998, p. 240)

One of the best eyewitness accounts of al-Mansur's mawlid celebrations is furnished by the notable 'Ali b. Muhammad al-Tamagruti, who al-Mansur sent on a diplomatic mission to the Ottoman Empire in 1589. Upon his return to Morocco, al-Tamagruti witnessed the celebration of the mawlid in 1591, and he provides us with a flowery panegyric description of the ceremony's significance for its participants. Al-Mansur, writes al-Tamagruti, celebrated the mawlid 'in the most perfect of fashions' (al-Tamagruti 1929, p. 87). Although al-Mansur's glorious al-Badi' palace was still under construction, the celebration was held within the grand courtyard. Al-Tamagruti writes,

Everyone was admitted, but each was placed according to the rank that his role assigned him, the class to which he was connected by origin. They all took their place under the dome ... and they could well imagine that they were within the gardens of paradise. Donning his most stunning costume, which heightens his majestic and imposing appearance, the sultan - May God grant him victory - took his habitual place. Everyone contemplated him with respect and admiration. (al-Tamagruti 1929, p. 89)

Al-Tamagruti goes on to describe in great detail the same elements that are mentioned by other writers as standard practice for mawlid celebrations: the meal ('They are served everything that the stomach could desire and that the eyes take pleasure in viewing', p. 90), the poetry ('The poets recite eulogies for the generous Prophet, celebrating the excellence of his holy birth; eulogies conceived in choice terms, in excellent style, with an overflowing eloquence ... pronounced in a smooth and vibrant voice, with an admirable cadence', p. 91), the rewards for the poets ('The Commander of the Faithful, to reward their zeal, rained down gifts and presents that surpass the number of the raindrops upon the performers of this entertainment', p. 91), and the closing prayer ('A humble prayer is 
addressed to God Most High ... on behalf of our lord the caliph, that his influence will last, his power will be made firm, he will be granted victory, that God will preserve the good qualities with which He has filled him', p. 92) The upshot of all of this for al-Tamagruti is very clear: al-Mansur's celebration of the Prophet's birthday served to strengthen the people's devotion and admiration for both the Prophet and his sharifian descendant, al-Mansur. ${ }^{24}$

Such celebrations were part of a larger strategy in which the sharifian sultan was presented to his people in his role as amir al-mu'minin ('Commander of the Faithful', a caliphal title) and ultimate political authority within Morocco. Their usefulness in this regard is attested to by the fact that similar approaches towards achieving political legitimacy were likewise pursued by the succeeding 'Alawi dynasty. And yet, an effective use of propaganda could not by itself overcome the ramifications of a violent succession crisis and the incompetent rule of later Sa'di sultans. By the mid-seventeenth century, the Sa'di dynasty had come to an end.

\section{The success of the sharifian 'asabiyah}

At first glance, the end of Sa'di rule seems to conform to the same dynastic process described by Ibn Khaldun and which operated in the histories of the earlier Moroccan states. Following the death of al-Mansur in 1603, a civil war broke out among his three sons, each of whom tried to enforce his own sovereignty over the country. Weakened by years of warfare, the dynasty lost control over most of the countryside and desert regions, over the Atlantic coastal cities, and over the Rif Mountains. During more than 60 years of fitna, regional, tribal and religious forces controlled Morocco. The constant battles resulted in an increase in famines, epidemics and pillaging until a new power arose in the Tafilalt oasis. Like the dynasties that had preceded them, the 'Alawis swept forth from the southern desert regions and were able to gain ascendancy throughout the country. In the end, the Sa'di state lasted about as long as its predecessors had, a little less than 150 years.

But though these facts seem to indicate another round of the Khaldunian Cycle, the foundations for transformation had been laid. It is significant that the new rulers were not just one more nomadic group mobilised by a religious reformer and combining Islamic zeal with tribal 'asabiyah. ${ }^{25}$ Rather, the 'Alawis were another sharifian family and, like the Sa'dis, they based their dynastic authority on this identity. In fact, the earliest 'Alawi apologists felt the need to attack Sa'di legitimacy not on the basis of presumed irreligious practices or injustices but upon the claim that the Sa'dis had not really been true shurafa' but instead had descended from the line of the Prophet's wet nurse. ${ }^{26}$ In addition, the early 'Alawis supported their own legitimacy through rhetoric, symbolism and imagery that bore striking resemblances to those of the Sa'dis. ${ }^{27}$

Ironically, the chaos of the seventeenth century further developed a national identity that had first appeared during the early Sa'di period, and served to solidify the borders of Morocco under the leadership of a sharifian prince. By the time the 'Alawis re-established a form of central control, international circumstances dictated that the caliph in Morocco had to content himself with exercising his command within that land alone, rather than asserting claims to caliphal authority over neighbouring Islamic territories, as earlier Moroccan dynasties had done. ${ }^{28}$ Thus, although they utilised much of the same rhetoric and imagery as the Sa'dis, including the pure white jellaba worn by the sultan, the parasol, and the caliphal title amir al-mu'minin, for the most part the "Alawis did not attempt to enforce their claims beyond the comparatively welldefined Moroccan borders. This more limited focus seems to have heightened a sense of a unique Moroccan identity, which included sharifian caliphal leadership.

Mulay Isma' $i l$, the second 'Alawi sultan to rule over a united Morocco, maintained his power over the course of a 55 year reign through a combination of repression, creative organisation, 
grand displays of power, and the establishment of a large private army of black slave soldiers called the 'abid. It is said that Mulay Isma'il's authority was so strongly enforced throughout the country that 'a Jew or a woman could go from Oujda to the Oued Noun without a soul daring to ask whence they came or whither they were going' (Julien 1970, p. 261). His strong hand undoubtedly consolidated 'Alawi rule over the country and his use of sharifian titles and symbolism to support his political legitimacy was no less important than that of his Sa'di predecessors. $^{29}$

Still, Mulay Isma'il expressed his sharifian authority in different ways than had Ahmad alMansur. Primary sources from his reign do not emphasise ceremonies such as the mawlid, but rather dramatic demonstrations of absolute power and religious zeal by the sultan. In this way, his reign can be compared with contemporary absolutist monarchs in Europe, some of whom he seems to have deliberately imitated. The grandeur of his enormous palace complex, huge number of slaves and political prisoners, and vast harem expressed the unwavering and absolute nature of his authority to his subjects and foreign visitors alike. ${ }^{30}$ An astute politician, Mulay Isma'il used the spiritual prestige of his lineage to undercut the religious authority of the Fezzi ulama and Idrisid shurafa'. Moving his capital to Meknes and starving Fez of the patronage that had made it great, Mulay Isma'il openly flaunted repeated denunciations of his actions by the Fezzi religious authorities, even as he emphasised his own spiritual significance as the sharifian amir al-muminin. ${ }^{31}$

Mulay Isma 'il's role as the supreme sharifian caliph was combined with a zealous pursuit of jihad. Although external conquest was no longer a realistic option, several European outposts remained ensconced along the Moroccan coast. Reclaiming the cities of Mazagan, Tangier and Larache from the colonial powers through military conquest, Mulay Isma 'il also sponsored an active oceanic jihad by the corsairs of Salé and Tetuan against European trading vessels. Ever the master of extravagant displays of power, the sultan is said to have personally 'owned more than fourteen hundred concubines from England, France, Spain and Portugal' (Matar 2005, p. 99). In his correspondence with the kings of England and France, Mulay Isma'il openly called for them to convert to Islam, an action which would 'resolve the conflict between their ... countries' (p. 162). He frequently used his European slaves in extensive work projects devoted to constructing a gigantic palace intended to rival the Versailles Palace of Louis XIV.

The vast number of the sultan's female companions and his prodigious offspring, ${ }^{32}$ when combined with his long reign, contributed to "Alawi dominance in a very practical way. The host of Mulay Isma 'il's descendants created an 'Alawi elite that supplanted the Idrisids as the dominant sharifian house in Morocco. In addition, the sultan established alliances with other sharifian families, such as the shurafa' of Wazzan. These alliances strengthened his hand in his lifelong struggle with the Fezzi religious authorities. ${ }^{33}$ By the end of his reign, Mulay Isma'il's dominance over the Fezzi ulama was so complete that he was able to co-opt their holiest shrine, reconstructing and embellishing the mausoleum of Idris II in an act of pious devotion and supreme religious authority (Cigar 1981, pp. 158-159). This action can also be seen as an attempt to bridge the difference between the various sharifian houses and to create a patronage system that provided a vested interest for the large sharifian caste to continue supporting the dynasty. ${ }^{34}$

Upon Mulay Isma 'il's death in 1727, however, the country deteriorated into political anarchy once again. In fact, those groups that had been the main props for Mulay Isma'il's control, his enormous family and his black slave army, actually contributed to the breakdown of central authority after he died. As the princes competed with one another for supremacy within a suddenly disjointed state, 'the 'abid wielded their considerable power to help make and unmake sultans during the thirty year period of anarchy from 1727 to 1757' (Cigar 1981, p. xxiii). Nevertheless, throughout this extended period of instability, no serious challengers arose to threaten 
'Alawi authority, which was re-established in 1757 by Sidi Muhammad ibn 'Abdallah. The political chaos returned upon the death of Sidi Muhammad in 1790, yet once again an 'Alawi sultan, Mulay Sulayman, was able to re-establish control. When the latter unwisely tried to break the power of a Berber confederation in the Middle Atlas, his army suffered a serious defeat in the Tadla in 1818 and the sultan himself was captured. Surprisingly, the rebels released him unharmed, demonstrating a respect for the office of the sharifian amir al-mu'minin even when they did not feel the necessity to obey his direct orders or pay taxes to his government.

The nineteenth century witnessed profound worldwide changes that Ibn Khaldun could never have predicted. The forces of Western expansion, economic globalisation, technological change, and new political and religious ideologies, which had begun to influence Morocco as early as the fifteenth century, reached their zenith at this time. While the sharifian governments had kept the Europeans at bay for several centuries, the Western intrusion came crashing in following the French conquest of Algeria in the 1830s and the British achievement of a free trade agreement with Morocco in 1856. As European influences increasingly pressed in upon Morocco, the sultans lost control over their country to a degree that far surpassed the Portuguese infringement upon Moroccan sovereignty in the fifteenth and sixteenth centuries.

Although the "Alawi sultans were largely blamed for their inability to keep out European influences, as the Wattasids had been, and a number of groups took jihad against the Europeans into their own hands, there was no movement comparable to the sixteenth century Sa' di conquests to threaten 'Alawi hold upon the sultanate. In fact the one successful rebellion against a sitting sultan took place against Sultan Abdelaziz during the crisis year of 1908. This movement gained success only because it was carried out in the name of another 'Alawi prince, Abdelaziz's brother Mulay Abdelhafid. While the competence and effectiveness of individual sultans could be challenged, few seemed to question the right of the "Alawi family to rule Morocco.

Thus, between 1662 and 1912, the 'Alawi dynasty had numerous opportunities to fall, and yet never did so. Unlike the past, there were no new groups arising from the desert or the mountains armed with religious zeal and abundant 'asabiyah and able to pose a significant threat to the dynasty, even when the "Alawi sultans were weak or the country was divided among competing pretenders. This fact is even more surprising when one considers that most "Alawi sultans never gained functional control over large portions of the country. The remote mountain and desert regions rarely paid taxes or obeyed the sultans' directives, and often were referred to as bilad alsiba (lands of rebellion). Yet rarely did the peoples of those lands directly challenge the dynasty's authority, and those who did so were unable to gather sufficient support to pose a significant threat. The few who rebelled against the sultan usually sought to add credibility to their challenge by backing a rival 'Alawi prince, as demonstrated by the 1908 rebellion against Sultan Abdelaziz.

Róbert Simon's explanation, that gunpowder technology, industrialisation and European colonialism provided the combination that broke the Khaldunian Cycle, seems inadequate to account for these circumstances in Morocco. There is no doubt that the influence of Western modernity was significant, but that influence was not expressed through transforming Moroccan society into the image of the West, at least not prior to the twentieth century. Instead, the West seems to have aided in the development of a new Moroccan 'asabiyah through its role as the Threatening Other, whose presence served to intensify popular support for what most Moroccans identified as 'their' government: rule by a sharifian prince from the 'Alawi house. Despite tribal, regional, linguistic, religious and cultural divisions, the one unique element that united Moroccans was their belief in the legitimacy of sharifian rule. In addition to their symbolic legitimacy, the 'Alawis' sharifian patronage system so completely dominated the country that 'lineages originating with Muhammad controlled most of the tariqas by the early nineteenth century' (Pennell 2000, p. 11).

During the twentieth century, sharifian/caliphal claims merged with nationalist impulses to create a powerful legitimising doctrine that would defend the dynasty against many challenges. 
This combination has served the 'Alawis well to the present day. For example, in the 1950s, Moroccan assertions of Muhammad V's rights as 'Commander of the Faithful' were expressions of national identity in opposition to French colonialism. Twentieth century 'Alawi sultans such as Muhammad V and Hassan II adroitly manipulated caliphal political and religious authority both to expel the French and to defuse radical Islamist movements within their borders. The current king, Muhammad VI, seeks to repackage the sharifian state yet again, promoting more openness and plurality in a modern context while striving to maintain the monarchy's traditional hold on power.

Thus, sharifian leadership has stood the test of time in Morocco, surviving not only the chaotic seventeenth and eighteenth centuries but also the traumatic colonial period of the nineteenth and twentieth centuries. To understand how unusual this situation is, one only needs to compare the twentieth century fates of monarchies in Turkey, Egypt, Libya, Iran, Afghanistan and Yemen, or the traditional governments of Algeria or Tunisia. In Morocco, broad support for sharifian legitimacy meant that the 'Alawis' hold on power was not seriously threatened even when their sultans were weak. Tribal leaders were content to exercise regional autonomy, while professing allegiance to the sharifian "Alawi caliph. This indicates that core elements of the Moroccan sharifian doctrine gained widespread support and demonstrated more resiliency than the political ideologies of comparable monarchies in other parts of the Islamic world.

\section{Conclusions}

Is it legitimate, then, to say that sharifianism has become an integral part of a new Moroccan asabiyah? ${ }^{35}$ Or is it even appropriate to use this term in the age of nationalism, powerful central governments and Western dominance? Certainly modern tools of repression and control make it easier for governments to stay in power long after they have lost their 'asabiyah. A glance at the current governments of Egypt, Tunisia and Syria (along with Iraq prior to the US invasion) confirms this point. The modern idea of nationalism presents another variable that Ibn Khaldun could hardly have anticipated. And finally, there is the fact that Western powers patronise governments that support their regional interests, providing an outside source of sustenance that was unknown at the time of Ibn Khaldun. ${ }^{36}$

Though times have indeed changed since the days of Ibn Khaldun, the general principles that he observed are still applicable within the modern world, albeit in different contexts and modified forms. ${ }^{37}$ 'Asabiyah remains a critical element in ethnic and regional autonomy and independence movements around the globe. Creating a national 'asabiyah is an important goal for every nationalist government, regardless of its political ideology. As a result of Western cultural hegemony and changing times, tribal 'asabiyah has become less of a force for governmental change, and the Bedouins, who Ibn Khaldun admired so much, are becoming something of an endangered species in many areas where they used to dominate. Broader forms of 'asabiyah, based upon religious, ethnic, or nationalist ideologies, rather than regional or tribal connections, dominate today's world.

In Morocco, the rise of sharifianism at a time when the concept of a separate Moroccan state was first becoming established allowed the idea of sharifian rule to become an integral part of the Moroccan identity. It also helped that Islam is widely viewed as the glue that holds together a very disjointed population and that the sharifian sultan is believed to be the one individual whose religious prestige allows him to bridge the gaps between the various groups. The contribution of visionary sultans such as Ahmad al-Mansur and Mulay Isma'il should also not be overlooked, as they provided effective rhetoric, ceremonies, imagery, and organisation used to reinforce the central importance of the sharifian amir al-mu'minin. In addition, the 'Alawi use 
of patronage and establishment of their family at the head of a new sharifian elite solidified their hold on political power.

Beyond these internal factors, the external threat provided by the growth of European influence galvanised Moroccan support for a political system through which they believed God would protect them from the infidel. The image of the holy warrior defending his lands against European intrusion was critical in establishing legitimacy for Sa'di sultans through the time of Ahmad al-Mansur and for the 'Alawi sultan Mulay Isma'il. Although Muhammad V did not call himself a holy warrior when he resisted French colonialism in the twentieth century, the effect of his resistance upon the Moroccan 'asabiyah was much the same as the sixteenth century jihads of the Sa'di sultans. It helped revive the prestige of a dynasty that had suffered a considerable loss of stature as a result of the expansion of European authority over the country.

To nineteenth century European visitors, Morocco seemed to be a ramshackle, anachronistic state built upon outmoded political and administrative systems, and which maintained a marginal and sporadic control over its diverse and fragmented populace. From their vantage point, the country needed to be completely remade along the model of advanced Western civilisation. And yet, less obvious to these foreign observers was a latent form of asabiyah, one sufficiently strong to enable the 'Alawi state to outlast Ibn Khaldun's predicted dynastic lifespan, breaking the Khaldunian Cycle in Morocco. When challenged by outside forces, this hidden 'asabiyah would develop into the basis for a new form of Moroccan nationalism that would eventually lead to the end of European colonialism in the country, and would also lay the foundations for an independent Moroccan state. Where the 'Alawi state will go from here is anybody's guess, but history suggests that, whatever transformations do take place, the sharifian 'asabiyah will continue to have an important role to play in the future of Morocco.

\section{Notes}

1. 'Asabiyah has been defined in a wide variety of ways. A. Hourani refers to it as 'a corporate spirit oriented towards obtaining and keeping power' (1991, p. 2). F. Baali and A. Wardi refer to it by the term 'group solidarity' (1981, p. 6). R. Simon lists a number of translations of 'asabiyah, including 'esprit de corps', 'faction', 'patriotism', 'fanaticism', 'chauvinism', 'faithfulness to the community', 'national passion', among many others (2002, pp. 149-150). For the purpose of this paper, I will use the term 'asabiyah directly, with the understanding that its meaning is close to Franz Rosenthal's translation of 'group feeling'.

2. Of the numerous writers who have taken this type of position, the work of Fuad Baali (1988, 2005, Baali and Wardi 1981) is representative. Baali's most recent work (2005) provides a detailed summary, with extensive references, of the various interpretations of Ibn Khaldun.

3. An exception is Aziz al-Azmeh, who provides an extensive analysis of Ibn Khaldun's work in several monographs (1981, 1982, 2000). Al-Azmeh seems to view Ibn Khaldun as something of a mediocre thinker, whose writing style is somewhat disorganised and whose points are unclear, but who owes his fame to the Orientalist desire to demonstrate the surpassing wisdom of modern European society by locating 'modern' ideas in the writings of a lone exceptional Arab thinker. Although Al-Azmeh makes a number of good points, he seems to be extreme in his criticisms of Ibn Khaldun, and R. Simon notes that Al-Azmeh's revisionist views 'have not revolutionized the Ibn Khaldun research at all' (2002, p. 65).

4. Despite the claim by Ibn Abi Zar, and the later histories that follow his account, that Fez was established by Idris II, most historians believe that the original foundations of the city were laid by the first Idris, even though it was not developed into a dynastic capital until the time of Idris II. Among the reasons for this are indications that Fez initially consisted of two cities, leading some to speculate that the older of the two was established by Idris I. For a summary of this argument, see E. Lévi Provençal (1939).

5. Mercedes García Arenal highlights the problem of studying the history of the Idrisids in the following quote: 'Despite (the) subsequent emphasis on the importance of the Idrisids, contemporary sources contain surprisingly little information on them' (2006, p. 45). 
6. Although they are often seen as a perfect example of the Khaldunian Cycle, Ronald Messier disputes this interpretation, arguing that it was the Almoravids' inability to adapt to settled civilisation, and not their being corrupted by an urban environment, that led to their downfall (Messier 2001).

7. Ibn Khaldun does see a connection between religious ideology and the development of asabiyah. He notes that dynasties often associate themselves with a particular religious doctrine in their rise to power, which serves to reinforce their sense of group feeling. This is because 'religious coloring does away with mutual jealousy and envy among people who share in a group feeling and causes concentration upon the truth' (Ibn Khaldun 1967, p. 126). Nevertheless, religious zeal without group feeling is insufficient to establish a dynasty. Ibn Khaldun discusses the example of numerous prophets and holy men whose movements failed for this reason. 'Many deluded individuals took it upon themselves to establish the truth', he writes. 'They did not know that they would need group feeling for that' (p. 127).

8. These two terms have become staples in the interpretation of Moroccan history, particularly during the 'Alawi period. They were popularised by European historians, who 'elaborated a theory of a country divided into two political areas, bilad al-makhzan, the Arabic-speaking plains and cities that obeyed the sultan, and bilad al-siba, the Berber-speaking mountains and deserts, that did not' (Pennell 2000, p. 28). This theory has been challenged in recent years as being overly simplistic. For a more nuanced discussion of this topic see Cigar (1981, pp. xxix-xxxiv) and Burke (1977, pp. 1-18).

9. See M. Kably (1999), who writes, 'We discover, in the accounts describing the space later known as alMaghrib al-Aqsa, the presence of (several) legitimising elements ... used alternatively by one or another dynasty in power' (p. 21).

10. In support of his claim to be the expected mahdi, Ibn Tumart represented himself as possessing sharifian ancestry, even though all evidence points to his Berber origins. Despite this claim by their founder, the Almohad dynasty established by Ibn Tumart never pushed the sharifian identity as a defining characteristic of the regime in the same way that the Sa'dis and 'Alawis would later do. For a discussion of Ibn Tumart's sharifian claims, see Cornell (1988).

11. A transitional dynasty, the Wattasids have largely been overlooked in the writings of modern historians. The classic work by Cour (1920) remains the standard text on the Wattasids 87 years after it was published.

12. For a detailed discussion of Wattasid motives for supporting the Idrisid cult and the political processes behind the establishment of the shrine of Idris II in Fez, see Beck (1989). It is interesting to note that the seventeenth century Fezzi historian Muhammad al-Qadiri blames the Berber dynasties for neglecting this shrine (Cigar 1981, pp. 161-162).

13. The best work on this short-lived city-state is an article by M. García Arenal (1978).

14. These outposts included Anfa (modern day Casablanca - 1469), Tangier (1471), Arzila (1471), Massat (1488), Santa Cruz de Aguer (modern day Agadir - 1505), Safi (1508), Azemmour (1513), Mazagan (1514) and Agouz (1519).

15. For more on the Sa'di challenge to the Wattasids, see Cornell (1998, pp. 241-244, 255-256); Cour (2004, pp. 65-75); Cour (1920, pp. 154-234).

16. For a discussion of al-Jazuli's life and impact, see Cornell (1998, pp. 155-195).

17. On the Hintata confederation and the Sa'di conquest of Marrakech, see P. Cenival (1937) and A. Dziubinski (1969).

18. Mahdist claims and movements established by would-be mahdis have played a significant role in the history of Morocco. For more on this, see M. García Arenal (2006). Her bibliography cites a number of other articles and books that discuss mahdist ideas and movements in Morocco.

19. The most complete works for a study of the rise of sharifian influence during the Merinid period are Beck (1989) and Kably (1986).

20. For more on this see Cory (2002).

21. For a fuller discussion of the historical development of the mawlid celebration, see Kaptein (1993).

22. al-Fishtali (1974, pp. 236-251); Ibn al-Qadi (1986, pp. 367, 375-376); al-Maqqari (1983, pp. 13-14); al-Tamagruti (1929, pp. 89-92).

23. Ibn al-Qadi asserts that this poem was recited during the mawlid celebration of 1587 (Ibn al-Qadi 1986, p. 367).

24. On the symbolic meaning of al-Mansur's mawlid celebrations, see E. Combs-Schilling $(1989,1999)$.

25. Norman Cigar argues that the 'Alawi conquest of Morocco was decidedly secular in nature, pointing out that the new rulers did not rise with the assistance of a new religious movement, as previous Moroccan dynasties had done. However, this does not mean that religious justification was unimportant to the 'Alawis. 'Although the dynasty's establishment could not be traced to any spiritual movement as such, 
the aura of descent from Muhammad, and the special intercessory role assigned to the shurafa' in Moroccan society since the Merinid times were exploited with considerable success. Protocol, titles, literature, all stressed this trait, as did close ties with shurafa' throughout the country' (Cigar 1981, p. xxv).

26. Al-Ifrani discusses these charges in detail in the first chapter of his history of the Sa'dis, written during the reign of Mulay Isma'il. See al-Ifrani (1998, pp. 28-39).

27. For a short summary of issues related to the religious legitimisation of the early "Alawi sultans, see Cigar (1981, pp. xxv-xxix).

28. Some of the regions claimed by earlier Moroccan dynasties included the following: The early Almoravid state included portions of what is now Mauritania and Mali as well as Islamic Spain (al-Andalus); the Almohads also conquered al-Andalus and extended their authority eastward all the way to Tripolitania in modern day Libya; the Merinids exerted influence within al-Andalus, and at times spread their authority eastward into what is now Algeria and even, for a time, Tunisia. The lands ruled by the Sa'dis, however, were roughly equivalent to the boundaries of what is now modern Morocco, with the exception of the short 12-year period in which al-Mansur ruled over the West African lands of the Songhay Empire, an area that includes portions of the modern nations of Mali, Niger, and Mauritania. After the Sa'dis, the boundaries of the Moroccan state remained fairly stable, since the Ottoman Empire restricted Moroccan monarchs from any eastward expansion, the Spanish Empire kept them from moving north, and southward expansion was made unfeasible due to the vastness of the Saharan desert and the growing involvement of the British and French in West Africa. After Mulay Isma'il, none of the "Alawi sultans was strong enough to even attempt expansion outside of the regions that were by now generally considered to comprise the Moroccan state. Instead, these sultans mostly turned their attention inwards and tried to limit the impact of outside influences upon their realms.

29. The eighteenth century chronicler Abu al-Qasem al-Zayyani notes the difficulty with which Mulay Isma'il established his authority over Morocco, writing that the sultan 'dedicated 24 years of his reign to pacifying the Maghrib and combating the insubordinate groups and those who rebelled against his authority. During this long period of time, he never spent one complete year undisturbed in his palace' (Zayyani, 1886, p. 46).

30. Despite his reputation as an absolute ruler, N. Cigar points out that even Mulay Isma'il was unable to maintain constant dominance over all the various competing groups within Moroccan society. His heavy-handed and adept practice of crushing any attempts at regional autonomy enabled him to achieve a greater degree of control than other Moroccan sultans, but even this relative hegemony would be immediately lost as soon as Mulay Isma'il died and was followed by other, less capable sultans (Cigar 1981, pp. xxix-xxxi).

31. The nineteenth century historian Ahmad al-Nasiri indicates that Mulay Isma'il chose Meknes as his capital in direct response to a Fezzi rebellion that occurred shortly after he became sultan. See alNasiri (1906, pp. 61-65).

32. Mulay Isma'il 'was credited with 700 sons and an uncounted number of daughters' (Julien 1970, p. 248).

33. Al-Zayyani's text captures some of the antipathy between Mulay Isma'il and the Fezzi religious authorities, as well as the sultan's eventual triumph over them. For example, he mentions an additional tax that Mulay Isma'il placed upon the ulama and shurafa' of Fez in 1721, because 'he was irritated with them' (Zayyani 1886, p. 53). In another place, he recounts Mulay Isma 'il's practice of sending officials to 'inspire a salutary terror' among the Fezzis (p. 51).

34. For more on Mulay Isma'il's use of sharifianism for political legitimacy, see Abun-Nasr (1987, pp. 234-237).

35. In referring to sharifianism as an important element in creating a modern Moroccan 'asabiyah, I fully acknowledge that I am applying this term in a way that Ibn Khaldun did not intend and in a manner that much more closely resembles the idea of a modern national consciousness. It will be remembered that Ibn Khaldun closely attached his conception of 'asabiyah to natural family and tribal relationships. He also believed that 'asabiyah was a quality that flourished in harsh environments such as deserts or remote mountains, and that it languished and died in more luxurious urban settings. Yet the sharifian 'asabiyah was mostly promoted and developed in urban environments, at least following the initial rise of the Sa'dis and the 'Alawis in the remote southern regions. Despite these facts, there is a degree to which modern nationalisms in the Middle East resemble a form of 'asabiyah, and have been referred to as such by a number of historians of the Middle East. The tribal basis for these nationalisms has led to much inter-communal violence in the Levant and Iraq, as events in recent decades have amply demonstrated. In contrast, inter-communal violence between Arabs and Berbers in Morocco has 
been almost non-existent, indicating the presence of a broader sense of Moroccan nationalism than can be found in countries like Iraq or Lebanon.

36. Of course, such support does not always guarantee the regime's survival as the spectacular failure of Muhammad Reza Shah in Iran demonstrates.

37. Ibn Khaldun himself acknowledges that times change and new circumstances require fresh historical interpretations. He criticises historians who disregard 'the fact that conditions within nations and races change with the change of periods and the passage of time' (1967, p. 24). In fact, 'when there is a general change of conditions, it is as if the entire creation had changed and the whole world been altered' (1967, p. 30). Thus, it makes sense that the substantial changes of the modern era should lead to a transformation in the forms of 'asabiyah used to sustain modern states.

\section{References}

Abun-Nasr, J., 1987. A history of the Maghrib in the Islamic period. Cambridge: Cambridge University Press.

Al-Azmeh, A., 1981. Ibn Khaldun in modern scholarship: a study in Orientalism. London: Third World Centre for Research and Publishing.

Al-Azmeh, A., 1982. Ibn Khaldun, an essay in reinterpretation. London: Cass.

Al-Azmeh, A., 2000. Ibn Khaldun. Beirut: Riyad al-Rayyis lil-Kutub wa-al-Nashr.

Baali, F., 1988. Society, state, and urbanism: Ibn Khaldun's sociological thought. New York: State University of New York Press.

Baali, F., 2005. The science of human social organization: conflicting views on Ibn Khaldun's (1332-1406) Ilm al-Umran. Lewiston, NY: Edwin Mellen Press.

Baali, F. and Wardi, A., 1981. Ibn Khaldun and Islamic thought-styles: a social perspective. Boston: G.K. Hall.

Beck, H., 1989. L'Image d'Idris II, ses descendants de Fas et la politique sharifienne des sultans Marinides (656-869/1258-1465). Leiden: E.J. Brill.

Brett, M. and Fentress, E., 1996. The Berbers. Oxford: Blackwell.

Burke, E.III, 1977. Prelude to protectorate in Morocco: precolonial protest and resistance, 1860-1912. Chicago: University of Chicago Press.

Cenival, P., 1937. Les emirs des Hintata, 'rois' de Marrakech. Hesperis, XXIV, 245-257.

Cigar, N., (ed), 1981. Muhammad al-Qadiri's Nashr al Mathani: the chronicles. London: Oxford University Press, trans.

Combs-Schilling, E., 1989. Sacred performances: Islam, sexuality, and sacrifice. New York: Columbia University Press.

Combs-Schilling, E., 1999. Performing monarchy, staging nation. In: R. Bourqia and S.G. Miller. In the shadow of the sultan: culture, power, and politics in Morocco. Cambridge, MA: Harvard University Press.

Cornell, V., 1983. The logic of analogy and the role of the Sufi Shaykh in post-Marinid Morocco. International journal of Middle East studies, 15, 67-93.

Cornell, V., 1988. Understanding is the mother of ability: responsibility and action in the doctrine of Ibn Tumart. Studia Islamica, 66, 71-103.

Cornell, V., 1990. Socioeconomic dimensions of reconquista and jihad in Morocco: Portuguese Dukkala and Sa'did Sus, 1450-1557. International journal of Middle East studies, 22, 379-488.

Cornell, V., 1996. The sovereignty of the Imamate (siyadat al-imama) of the Jazuliyya-Ghazwaniyya: a Sufi alternative to sharifism? Al-Qantara, 17, 429-451.

Cornell, V., 1998. Realm of the saint: power and authority in Moroccan Sufism. Austin: University of Texas Press.

Cory, S., 2002. Chosen by God to rule: the caliphate and political legitimacy in early modern Morocco. Unpublished dissertation, University of California Santa Barbara.

Cour, A., 1920. La Dynastie marocaine des Beni Wattas, 1420-1554. Constantine: Imprimerie D. Braham.

Cour, A., 2004. L'etablissement des dynasties des chérifs au Maroc et leur rivalite avec les Turcs de la régence d'Alger, 1509-1830. Reprinted by Abdelmajid Kaddouri. Paris: Editions Bouchene.

Dziubinski, A., 1969. Les chorfa Saadiens dans le Sous et á Marrakech jusqu'en 1525. Africana bulletin, 10, $31-51$.

al-Fishtali, A., 1974. Manahil al-safa fi ma'athir mawalina al-shurafa'. 'Abd al-Karim Kurayyim, ed. Rabat, Morocco: Matba'a al-Najah al-jadida. 
García Arenal, M., 1978. The revolution of Fas in 869/1465 and the death of sultan "Abd al-Haqq al-Marini. Bulletin of the School of Oriental and African Studies, 41, 43-66.

García Arenal, M., 2006. Messianism and puritanical reform: Mahdis of the Muslim West. M. Beagles, trans. Leiden: Brill.

Hourani, A., 1991. A history of the Arab peoples. Cambridge, MA: Harvard University Press, Reprinted (2005) as A history of the Arab peoples with an afterword by Malise Ruthven. Kent: Mackays of Bhatham.

Ibn Khaldun, A., 1867. Kitab al-'Ibar wa diwan al-mubtada' wa al-khabar fi ayyam al-'Arab wa al-'ajami wa al-Barbar 7 vols. Cairo: Bulaq.

Ibn Khaldun, A., 1967. The Muqaddimahh: an introduction to history. F. Rosenthal, trans., N.J. Dawood, ed. and abridged. Princeton, NJ: Princeton University Press.

Ibn al-Qadi, A., 1986. Al-Muntaqa al-maqsur 'ala ma'athir al-khalifa Abi al-Abbas al-Mansur M. Razzouq, ed. Rabat: Mektabat al-Ma'arif.

al-Ifrani, M., 1998. Nuzha al-hadi bi akhbar muluk al-qarn al-hadi. A. ' al-Shadili, ed. Casablanca: Matba' al-Najah al-Jadid.

Julien, C.A., 1970. History of North Africa: from the Arab conquest to 1830. J. Petrie, trans., C.C. Stewart, ed. New York: Praeger.

Kably, M., 1986. Societe, pouvoir et religion au Maroc a la fin du 'Moyen-Age' (XIVe-Xve). Paris: Maisonneuve et Larose.

Kably, M.,1999. Legitimacy of state power and socioreligious variations in medieval Morocco. In: R. Bourqia and S.G. Miller. In the shadow of the sultan: culture, power, and politics in Morocco. Cambridge, MA: Harvard University Press..

Kaptein, N.J.G., 1993. Muhammad's birthday festival: early history in the central Muslim lands and development in the Muslim West until the $10^{\text {th }} / 16^{\text {th }}$ century. Leiden: E.J. Brill.

Khalidi, T., 1994. Arabic historical thought in the classical period. New York: Cambridge University Press.

Lacoste, Y., 1984. Ibn Khaldun: the birth of history and the past of the Third World. D. Macey, trans. London: Verso.

Lévi Provençal, E., 1939. La foundation de Fes. Annles de l'Institut d'Etudes Orientales d'Alger, IV, 1-31.

al-Maqqari, A., 1983. Rawda al-as al-'atira al-anfas fi dhikr man laqitahu min 'a'lam al-hadratin Murakush wa Fas. A. Benmansour, ed. Rabat: Matba'a al-Malikia.

Matar, N., 2005. Britain and Barbary, 1589-1689. Gainesville, FL: University of Florida Press.

Messier, R., 2001. Re-thinking the Almoravids, re-thinking Ibn Khaldun. In: J. Clancy-Smith, ed. North Africa, Islam, and the Mediterranean world. London: Frank Cass.

al-Nasiri, A., 1906. Chronique de la dynastie Alaouie de Maroc, E. Fumey, trans. In: Archives Marocaines: publication de la mission scientifique du Maroc, Vol. IX. Paris: Ernest Leroux.

Pennell, C.R., 2000. Morocco since 1830, a history. London: Hurst.

Simon, R., 2002. Ibn Khaldun: history of science and the patrimonial empire. K. Pogátsa, trans. Budapest: Akadémiai Kiadó.

al-Tamagruti, A., 1929. En-Nafhat el-miskiya fi al-sifarat Turkiyya. Edited and translated by H. de Castries as Relation d'une ambassade marocaine en Turquie, 1589-1591. Paris: Paul Geuthner.

Yahya, D., 1981. Morocco in the sixteenth century: problems and patterns in African Foreign policy. Atlantic Highlands, NJ: Humanities Press.

Zayyani, A., 1886. Le Maroc de 1631 à 1812, extrait de l'ouvrage intitulé Ettordjeman El Mo'arib 'an douel El Machriq ou 'IMaghrib. O. Houdas, trans., E. Leroux, ed. Paris: Imprimerie Nationale. 